\title{
A Value-oriented Framework for Inventory Management
}

Grzegorz Michalski *

\section{Abstract:}

The basic financial purpose of a firm is to maximize its value. An inventory management system should also contribute to the realization of this basic aim. Many current asset management models found in financial management literature were constructed with the assumption of book profit maximization as their basic aim. However these models could lack the means for realizing a different aim, i.e., the maximization of enterprise value. This article presents a modified value-based inventory management model.

Keywords: inventory management, value-based management, free cash flow, working capital management, short-run financial management

\section{Introduction}

The basic financial aim of an enterprise is the maximization of its value. At the same time, research into the determinants in increasing firm value has considerable theoretical and practical significance. Most financial literature contains information about numerous factors influencing value. Among those factors are net working capital and the elements creating it, such as the level of cash tied in accounts receivable, inventories and operational cash balances. A large majority of classic financial model proposals related to optimum current assets management were constructed with net profit maximization in view. In order to make these models more suitable for firms that want to maximize their value, some of them must be reconstructed. In the sphere of inventory management, the estimation of the influence of changes in a firm's decisions is a compromise between limiting risk by having greater inventory and limiting the costs of inventory. It is the essential problem of corporate financial management.

Current assets, i.e. the sum of inventories, accounts receivable, short-term investment (cash and equivalents) and short term accruals [Mueller 1953; Graber 1948; Khoury 1999; Cote 1999] are for the firm collateral/protection against risk [Merton 1999, p. 506;
Lofthouse 2005; p. 27-28; Parrino 2008, p. 224-233, Poteshman 2005, p. 21-60] and at the same time an investment [Levy 1999, p. 6; Reilly 1992, p. 6; Fabozzi 1999, p. 214]. Current assets level is the result of a kind of production organization [Baumol 1952, Beck 2005, Beranek 1963, Emery 1988, Gallinger 1986, Holmstrom 2001, Kim 1998, Kim 1978, Lyn 1996, Tobin 1958, Stone 1972, Miller 1966, Miller 1996, Myers 1998, Opler 1999]. As a result, the firm maintains an adequate level of inventories and is linked with operational management rather than with financial decisions [Peterson 1979, p. 6769; Orlicky 1975, p.17-19; Plossl 1985, p. 421]. At the same time, current assets are the result of an active policy of gaining and holding the firm's clients. [Bougheas 2009] The firm offer should be suited to the demands and character of the firm clients. Inventory levels are also a result of this policy.

The basic financial purpose of an enterprise is the maximization of its value. Inventory management should

\footnotetext{
* Grzegorz Michalski

Department of Corporate Finance and Value Management, Wroclaw University of Economics e-mail: Grzegorz.Michalski@ae.wroc.pl
} 
also contribute to the realization of this fundamental aim. Many of the current asset management models that are found in financial management literature assume book profit maximization as their basic financial purpose. These book profit-based models could be lacking with regard to another aim, i.e., the maximization of enterprise value. The enterprise value maximization strategy is executed with a focus on risk and uncertainty. This article presents the consequences for the recipient firm that can result from operating risk related to the delivery risk generated by suppliers. The present article offers a method using portfolio management theory to choose suppliers.

When the entrepreneur chooses the tradesman, the entrepreneur should concentrate his or her attention not only on basic knowledge about the contracting party's individual shape parameters (i.e. the tradesman's financial situation), but also on information from inventory management models.

The basic financial inventory management aim is to hold inventory to a minimally acceptable level in relation to costs. Holding inventory means using capital to finance inventory and links with inventory storage, insurance, transport, obsolescence, waste and spoilage costs. However, maintaining a low inventory level can, in turn, lead to other problems with regard to meeting supply demands.

\section{Value based inventory management}

If advantages from holding inventory on a level defined by the firm are greater than the negative influence of opportunity costs from its holding, then the firm's value will grow. Change of inventory level affects the firm value. To measure that value, a formula can be used that is based on the assumption that the firm value is a sum of future free cash flows to the firm (FCFF) discounted by the cost of the capital financing the firm:

$$
\Delta V_{p}=\sum_{t=1}^{n} \frac{\Delta F C F F_{t}}{(1+k)^{t}},
$$

where $\Delta V_{p}=$ firm value growth; $\triangle F C F F_{t}=$ future free cash flow growth in period $t$, and $k=$ discount rate'.

Future free cash flow is expressed:

\footnotetext{
1 To estimate changes in accounts receivable levels, a discount rate equal to the average weighted cost of capital (WACC) is accepted. Such changes and their results are strategic and long term in character, although they refer to accounts receivable and short run area decisions (T.S. Maness 1998, s. 62-63)
}

$$
\begin{aligned}
F C F F_{t}=\left(C R_{t}-C E_{t}-N C E\right) \times(1-T)+ \\
+N C E-C \text { apex }-\Delta N W C_{t}
\end{aligned}
$$

where $C R_{t}=$ cash revenues on sales; $C E_{t}=$ cash expenses resulting from fixed and variable costs in time $t ; N C E=$ non-cash expenses; $T=$ effective tax rate; $\triangle N W C=$ net working growth; and Capex = capital expenditure resulting from operational investments growth (money used by a firm to acquire or upgrade physical assets such as property, industrial buildings, or equipment).

Similar conclusions about the results of a change in inventory management policy on firm value can be estimated on the basis of economic value added, which reveals the size of the residual profit (the added value) and enlargement of the firm's value in the period:

$$
E V A=N O P A T-k \times(N W C+O I),
$$

where $E V A=$ economic value added; $N W C$ = net working capital; $\mathrm{Ol}=$ long-term operating investments; and NOPAT $=$ net operating profit after taxes, estimated on the basis of the formula:

$$
N O P A T=\left(C R_{t}-C E_{t}-N C E\right) \times(1-T)
$$

The net working capital (NWC) is a part of current assets financed with fixed capital. The net working capital (current assets less current liabilities) results from the lack of synchronization of the formal rising receipts and the real cash receipts from each sale. Net working capital also results from divergence during a time of rising costs and from the real outflow of cash when a firm pays its accounts payable.

$N W C=C A-C L=A A R+I N V+G-A A P$

where $N W C=$ net working capital; $C A=$ current assets; $C L$ $=$ current liabilities; $A A R=$ average level of accounts receivable; $I N V=$ inventory; $G=$ cash and cash equivalents; and $A A P=$ average level of accounts payable.

During estimation of the free cash flows the holding and increasing of net working capital ties money used for financing it. If net working capital increases, the firm must tie money, thus decreasing free cash flows. Production level growth usually creates a necessity for the enlargement of cash levels, inventories, and accounts receivable. Part of this growth will be covered by current liabilities. Current liabilities also usually automatically increase alongside growth in production. The rest (which is noted as net working capital growth) will require other forms of financing. 
Inventory management policy decisions create the new inventory level in a firm. These decisions have influence on firm value. It is the result of opportunity costs of money tied in with inventory and the general costs of inventory management. Both the first and second involve the modification of future free cash flows, leading to changes in firm value. Figure 1 shows the influence of inventory management decisions on firm value. These decisions change the future free cash flows (FCFF). These decisions could also have influence on the life of the firm $(t)$ (by the operational risk, which is the result of the possibility of a break in production cycles if the inventory level is too low), and the rate of the cost of capital financing of the firm $(k)$. Changes to these three components have an influence on the creation of firm value $(\Delta V p)$.

Influence on FCFF
Influence on $k$
Influence on $t$
Inventory changes influences:
$\bullet \quad$ costs
\[ N W C \]
Inventory changes could influence cost of capital
Inventory changes could influence period of life of the
$\quad$ enterprise.
$\Delta V=\sum_{t=1}^{n} \frac{\Delta F C F F_{t}}{(1+k)^{t}}$
$E V A=N O P A T-k \times(N W C+I O)$

where $F C F F=$ free cash flows to firm; $\triangle N W C=$ net working capital growth; $k=$ cost of the capital financing the firm; and $t=$ the lifetime of the firm and the time required to generate single FCFF.

Figure 1: Influence of inventory management decisions on firm value Source: own study.

Inventory changes (resulting from changes in the inventory management policy of the firm) affect the net working capital level and the level of operating costs of inventory management in a firm as well. These operating costs are the result of storage, insurance, transport, obsolescence, waste and spoilage of inventory.

\section{EOQ and VBEOQ}

The Economic Order Quantity Model is a model which maximizes the firm's income through total inventory cost minimization.

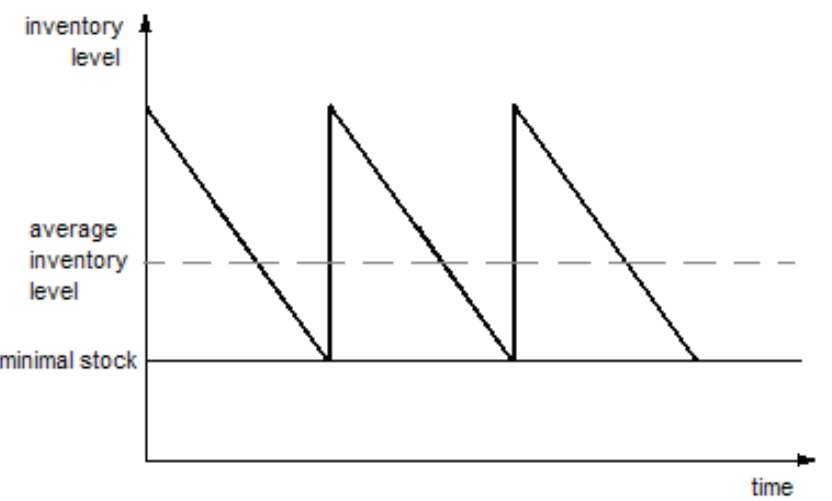

Figure 2: $E O Q$ and VBEOQ model

Source: J. G. Kalberg, K. L. Parkinson, Corporate liquidity: Management and Measurement, IRWIN, Homewood 1993, p. 538.

The EOQ model requires two equations:

$E O Q=\sqrt{\frac{2 \times P \times K_{z}}{C \times v}}=\sqrt{\frac{2 \times P \times K_{z}}{K_{u}}}$,

where $E O Q=$ economic order quantity; $P=$ demand for the product/inventory in period (year, month); $K_{z}=$ cost per order; $K_{u}=$ holding cost per unit in period (year, month); $C=$ holding cost factor; and $v=$ purchase cost per unit.

The holding cost factor $\left(K_{u}\right)$ is a result of the following costs ${ }^{2}$ :

- Opportunity costs (price of money tied-up in inventory)

- Storage, insurance, transportation, obsolescence, waste and spoilage costs

$T C I=\frac{P}{Q} \times K_{z}+\left(\frac{Q}{2}+z_{b}\right) \times v \times C$,

where $T C l=$ total costs of inventory; $Q=$ order quantity; and $z_{b}=$ minimal stock.

Example 1. $P=220000 \mathrm{~kg} ; \quad K_{z}=31 \$ ; \quad v=2 \$ / 1 \mathrm{~kg} ;$ $C=25 \%$. Effective tax rate, $T=19 \%$. Cost of capital financing the firm $W A C C=k=15 \% ; z_{b}=300 \mathrm{~kg}$.

First $E O Q$ is estimated:

2 M. Sierpińska, D. Wędzki, Zarządzanie płynnością finansowa $w$ przedsiębiorstwie, WN PWN, Warszawa 2002, s. 112. 
$E O Q=\sqrt{\frac{2 \times 220000 \times 31}{0,25 \times 2}}=5223 \mathrm{~kg}$.

Next average inventory level is estimated:

$$
\begin{aligned}
& I N V_{E O Q=5223}= \frac{5223}{2}+300=2912 \mathrm{~kg} \Rightarrow \\
& \Rightarrow I N V_{E O Q=5223}=2912 \times 2=5824 \$ \\
& T C I_{E O Q=5223}=\frac{220000}{5223} \times 31+ \\
&+\left(\frac{5223}{2}+300\right) \times 2 \times 0,25=2762 \$
\end{aligned}
$$

If $5000 \mathrm{~kg}$ are ordered, the quantity $E O Q=5223 \mathrm{~kg}$, and the $\mathrm{TCl}$ are:

$$
\begin{aligned}
T C I_{Q=5000}= & \frac{220000}{5000} \times 31+ \\
& +\left(\frac{5000}{2}+300\right) \times 2 \times 0,25=2764 \$ .
\end{aligned}
$$

$T C l$ will be greater, but if its influence on firm value is checked, it will be seen that if the decision is made to order less than EOQ suggests, this will increase the firm value:

$$
\begin{aligned}
& \Delta T C I_{Q=5223 \rightarrow Q=5000}=2764-2762=2 \$, \\
& I N V_{Q=5000}=2 \times\left(\frac{5000}{2}+300\right)=5600 \$, \\
& \Delta I N V_{Q=5223 \rightarrow Q=5000}=5600-5824=-224 \$, \\
& \Delta N W C=\Delta I N V, \\
& \Delta V_{Q=5223 \rightarrow Q=5000}=224-\frac{2 \times(1-0,19)}{0,15}=213,2 \$ ; \\
& \Delta E V A_{Q=5223 \rightarrow Q=5000}=\Delta N O P A T-k \times(\Delta N W C+\Delta O I) \\
& \quad=(1-0,19) \times(-2)-0,15 \times(-224)=32 \$ .
\end{aligned}
$$

Because both $\triangle \mathrm{V}$ and $\triangle \mathrm{EVA}$ are greater than 0 , it can bee seen that it will be profitable for the firm to order $5000 \mathrm{~kg}$, not $5223 \mathrm{~kg}$ as suggested by EOQ. The EOQ model minimizes operational inventory costs, but in firm management there are also the opportunity costs of holding inventories. These costs dictate that the order will be less than that suggested by $E O Q$ so as to maximize the firm value. With this in mind the $V B E O Q$ model can be used:

$$
V B E O Q=\sqrt{\frac{2 \times(1-T) \times K_{Z} \times P}{v \times(k+C \times(1-T))}}
$$

where $k=$ cost of capital financing the firm (WACC); and $V B E O Q=$ value based economic order quantity.

\section{For Alfa data:}

$$
\begin{aligned}
& V B E O Q=\sqrt{\frac{2 \times(1-0,19) \times 31 \times 220000}{2 \times(0,15+0,25 \times(1-0,19))}}=3959 \mathrm{~kg} \text {; } \\
& T C I_{\text {VBEOQ }=3959}=\frac{220000}{3959} \times 31+ \\
& +\left(\frac{3959}{2}+300\right) \times 2 \times 0,25=2862 \$ ; \\
& \Delta T C I_{Q=5223 \rightarrow Q=3959}=2862-2762=100 \$ \text {; } \\
& I N V_{V B E O Q=3959}=2 \times\left(\frac{3959}{2}+300\right)=4559 \$ \text {; } \\
& \Delta I N V_{Q=5223 \rightarrow Q=3959}=4559-5824=-1265 \$ \text {; } \\
& \Delta V_{Q=5223 \rightarrow Q=3959}=1265-\frac{100 \times(1-0,19)}{0,15}=725 \$ \text {; } \\
& \triangle E V A_{Q=5223 \rightarrow Q=3959}= \\
& (1-0,19) \times(-100)-0,15 \times(-1265)=109 \$ .
\end{aligned}
$$

Both $\triangle \mathrm{V}$ and $\triangle \mathrm{EVA}$ are greater than before if the firm's order of $3959 \mathrm{~kg}$ is marked by VBEOQ. In fact it is the best known possibility.

\section{4. $P O Q$ and $V B P O Q$}

A production order quantity model $(P O Q)$ is an EOQ modification that can be used when production possibilities exceed the market's capacity.

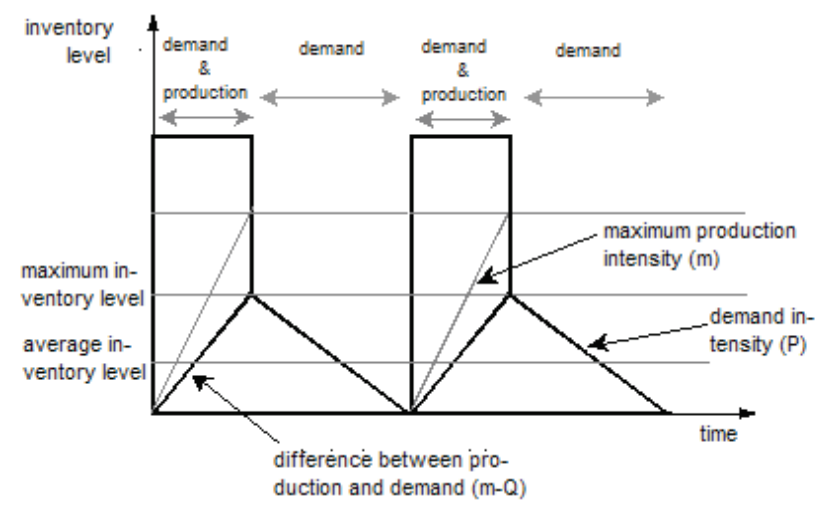

Figure 3: $\mathrm{POQ}$ and VBPOQ

Source: Z. Sariusz-Wolski, Sterowanie zapasami w przedsiębiorstwie, PWE, Warszawa 2000, p. 162.

POQ could be estimated as $^{3}$ :

$$
P O Q=\sqrt{\frac{2 \times K_{z} \times P}{C \times k \times\left(1-\frac{P}{m}\right)}}, P<m
$$

\footnotetext{
3 Z. Sariusz-Wolski, Sterowanie zapasami w przedsiębiorstwie, PWE, Warszawa 2000, s. 162
} 
where $P O Q=$ production order quantity; $K_{z}=$ switch on production cost (setup cost per setup); $P=$ demand intensity (how much can be sold annually); $v=$ cost per unit; $m=$ maximum annual production ability; and $C=$ holding cost factor.

$$
T C I=\frac{Q}{2} \times\left(1-\frac{P}{m}\right) \times v \times C+\frac{P}{Q} \times K_{z}
$$

where $Q=$ production quantity; and $T C l=$ total cost of inventories.

$$
I N V=\frac{Q}{2} \times\left(1-\frac{P}{m}\right)
$$

Where $I N V=$ average inventory level.

Example 2. Maximum demand, $\mathrm{P}=2500$ tons, $\mathrm{m}=$ 10000 tons annually. WACC $=k=15 \%, C=25 \%, T=$ $19 \% . K_{z}=12000 \$, v=0,8 \$$.

First $P O Q$ is estimated:

$$
\begin{gathered}
P O Q=\sqrt{\frac{2 \times 12000 \times 2500}{800 \times 0,25 \times\left(1-\frac{2500}{10000}\right)}}=633 \text { tons. } \\
T C I_{P O Q=633}=\frac{633}{2} \times\left(1-\frac{2500}{10000}\right) \times 800 \times 0,25+ \\
+\frac{2500}{633} \times 12000=94868 \$ .
\end{gathered}
$$

$$
\begin{array}{r}
I N V_{P O Q=633}=\frac{633}{2} \times\left(1-\frac{2500}{10000}\right)=237(1000) \mathrm{kg} . \\
\Rightarrow 237 \times 800=189600 \$
\end{array}
$$

The following check the influence of firm value on the change of production quantity to $90 \% \mathrm{POQ}$, $633 \times 0,9=570$ tons:

$$
\begin{aligned}
& T C I_{P O Q=570}=\frac{570}{2} \times\left(1-\frac{2500}{10000}\right) \times 800 \times 0,25+ \\
& +\frac{2500}{570} \times 12000=95382 \$, \\
& \begin{aligned}
\frac{-\Delta F C F F_{1 \ldots \infty}}{0,81}=\Delta T C I_{Q=633 \rightarrow Q=570} \\
=95382-94868=514 \$ .
\end{aligned}
\end{aligned}
$$

$I N V_{P O Q=570}=800 \times I N V_{570}$

$$
=800 \times \frac{570}{2} \times\left(1-\frac{2500}{10000}\right)=171000 \$,
$$

$\triangle N W C=\left(-\triangle F C F F_{0}\right)=\triangle Z A P_{Q=633 \rightarrow Q=570}$

$$
=171000-189600=(-18600) \$ \text {. }
$$

$\Delta V_{Q=633 \rightarrow Q=570}=+18600+\frac{-514 \times(1-0,19)}{0,15}$

$$
=+15824 \$ \text {, }
$$

$$
\begin{aligned}
& \Delta E V A_{Q=633 \rightarrow Q=570} \\
& \quad=(1-0,19) \times(-514)-0,15 \times(-18600)=2373,66 \$
\end{aligned} .
$$

This shows that if production is less than the quantity POQ additional value will be created.

VBPOQ can be determined from the following table:

\begin{tabular}{|c|c|c|c|c|c|l|}
\hline $\mathrm{Q}$ & $\mathrm{TCl}$ & $\Delta \mathrm{TCl}$ & $\mathrm{INV}$ & $\Delta \mathrm{INV}$ & $\Delta \mathrm{V}$ & $\Delta \mathrm{EVA}$ \\
\hline 483 & 98337 & 3469 & 144900 & -44700 & 25968 & 3895 \\
\hline 482 & 98391 & 3523 & 144600 & -45000 & 25978 & 3896 \\
\hline 481 & 98445 & 3577 & 144300 & -45300 & 25984 & 3898 \\
\hline 480 & 98500 & 3632 & 144000 & -45600 & 25987 & 3898 \\
\hline 479 & 98555 & 3687 & 143700 & -45900 & 25988 & 3899 \\
\hline 478 & 98612 & 3744 & 143400 & -46200 & 25985 & 3897 \\
\hline 477 & 98668 & 3800 & 143100 & -46500 & 25980 & 3897 \\
\hline
\end{tabular}

Table 1: VBPOQ

Source: own study

From this it was found that VBPOQ gives 479 tons. Table 1 also shows that the costs TCI for VBPOQ will be greater than for POQ, but that VBPOQ ties up less cash in inventories than the $\mathrm{POQ}$, which is the source of benefits in lower opportunity costs.

To estimate VBPOQ the following equation could also be used:

$$
\begin{aligned}
& Q_{V B P O Q}=\sqrt{\frac{2 \times P \times K_{z} \times(1-T)}{v \times\left(1-\frac{P}{m}\right) \times[k+C \times(1-T)]}}, P<m \\
& Q_{V B P O Q}=\sqrt{\frac{2 \times 2500 \times 12000 \times(1-0,19)}{800 \times\left(1-\frac{2500}{10000}\right) \times[0,15+0,25 \times(1-0,19)]}}=479 \text { tons. }
\end{aligned}
$$

Knowing $V B P O Q$, the firm can better manage inventories and bring the firm closer to realizing its basic financial aim - firm value maximization. 


\section{Conclusions}

Maximization of the owners' wealth is the basic financial goal in enterprise management. Inventory management techniques must contribute to this goal. Modifications to both the value-based EOQ model and value-based $P O Q$ model may be seen in this article. Inventory management decisions are complex. Excess cash tied up in inventory burdens the enterprise with high costs of inventory service and opportunity costs. By contrast, higher inventory stock helps increase income from sales because customers have greater flexibility in making purchasing decisions and the firm decreases the risk of unplanned breaks in production. Although problems connected with optimal economic order quantity and production order quantity remain, it can be concluded that the value-based modifications implied by these two models will help managers make better valuecreating decisions in inventory management. ㄷ.

\section{Literature}

BRIGHAM E.F., DAVES P.R., Intermediate Financial Management, Thomson, Mason 2004.

FABOZZI F. J., G. FONG, Zarządzanie portfelem inwestycji finansowych przynoszacych stały dochód, WN PWN, Warszawa 2000.

FABOZZI F.J., Investment Management, Prentice Hall, Upper Saddle River 1999.

JAJUGA K., Zarządzanie kapitałem, Wydawnictwo AE, Wrocław 1993.

LUENBERGER D. G., Teoria inwestycji finansowych, WN PWN, Warszawa 2003.

MANESS T.S., J.T. ZIETLOW, Short-Term Financial Management, Dryden Press, Fort Worth 1998.

MICHALSKI G., Leksykon zarządzania finansami, CHBeck, Warszawa 2004.

PIOTROWSKA M., Finanse spółek. Krótkoterminowe decyzje finansowe, Wydawnictwo AE, Wrocław 1997.

PLUTA W., G. MICHALSKI, Krótkoterminowe zarządzanie kapitałem, CHBeck, Warszawa 2005.

SARTORIS W., HILL N., A Generalized Cash Flow Approach to Short-Term Financial Decisions, [in:] Pogue A., "Cash and Working Capital Management", The Journal of Finance, May 1983, s. 349-360.

SCHERR F. C., Modern Working Capital Management. Text and Cases, Prentice Hall, Englewood Cliffs 1989.

SIERPIŃSKA M., WĘDZKI D., Zarządzanie płynnościa finansowa $w$ przedsiębiorstwie, WN PWN Warszawa 2005.

BAUMOL W.J., The Transactions Demand for Cash: An Inventory

Theoretic Approach, Quarterly Journal of Economics", nr 66, Nov 1952, p. 545-556.

BECK S.E., D.R. Stockman, Money as Real Options in a Cash-in-Advance Economy, Economics Letters, 2005, vol. 87, p. 337-345.

BERANEK W., Analysis for Financial Decisions, R. D. IRWIN, Homewood 1963.

BOUGHEAS S., Mateut S., Mizen, P., Corporate trade credit and inventories: New evidence of a trade-off from accounts payable and receivable, Journal of Banking \& Finance, vol. 33, no. 2, 2009, p. 300-307.
COTE J.M., C.K. Latham, The Merchandising Ratio: A Comprehensive Measure of Working Capital Strategy, Issues in Accounting Education, vol. 14, no. 2, May 1999, p. 255-267.

EMERY G.W., Positive Theories of Trade Credit, Advances in Working Capital Management, JAI Press, vol. 1, 1988, p. 115-130.

GALLINGER G., A. J. Ifflander, Monitoring Accounts Receivable Using Variance Analysis Financial Management, 1986, 69-76.

GRABER P.J., Assets, The Accounting Review, vol. 23, no. 1, Jan. 1948, p. 12-16.

HOLMSTROM B., J. Tirole, LAPM: a liquidity-based asset pricing model, Journal of Finance, 2001, vol. 56, p. 1837-1867 \{WP6673, National Bureau of Economic Research, Cambridge, 1998\}.

KALBERG J. G., K. L. Parkinson, Corporate liquidity: Management and Measurment, IRWIN, Homewood 1993.

KHOURY N.T., K.V. Smith, P.I. MacKay, Comparing Working Capital Practices in Canada, the United States and Australia, Revue Canadienne des Sciences de l'Administration, vol. 16, no. 1, Mar. 1999, p. 53-57.

KIM C-S., D. C. Mauer, A. E. Sherman, The Determinants of Corporate Liquidity: Theory and Evidence, Journal of Financial and Quantitative Analysis, vol. 33, nr 3, 1998.

KIM Y. H., J. C. Atkins, Evaluating Investments in Accounts Receivable:

A Wealth Maximizing Framework, Journal of Finance, vol. 33, nr 2, 1978, p. 403-412.

LEVY H., D. Gunthorpe, Introduction do Investments, South-Western College Publishing, Cincinnati 1999.

LOFTHOUSE S., Investment Management, Wiley, Chichester 2005. LYN E. O., G. J. Papaioannou, Liquidity and the Financing Policy of the Firm: an Empirical Test, Advances in Capital Management, Londyn 1996, vol. 3, p. 65-83.

MERTON R.C, A.F. Perold, Theory of Risk Capital in Financial Firms, w: D.H. Chew, The New Corporate Finance. Where Theory Meets Practice, McGraw-Hill, Boston 1999.

MILLER M.H., D. Orr, A Model of the Demand for Money by Firms, Quarterly Journal of Economics, 1966, nr 80, p. 413-435.

MILLER T. W., B. K. Stone, The Value of Short-Term Cash Flow

Forecasting Systems, Advances in Working Capital Management, JAI Press Inc., London 1996, vol. 3, p. 3-63.

MUELLER F.W., Corporate Working Capital and Liquidity, The Journal of Business of the University of Chicago, vol. 26, no. 3, Jul. 1953, p. 157-172.

MYERS S. C., R. G. RAJAN, The Paradox of Liquidity, Quarterly Journal of Economics 113, nr 3, Cambridge, 1998, p. 733-771.

OPLER T., R. STULZ, R. Williamson, The determinants and implications of corporate cash holdings, Journal of Financial Economics, vol. 52, no. 1, 1999, p. 3-46.

ORLICKY J., Material Requirements Planning, McGraw-Hill, New York 1975.

PARRINO R., D.S. Kidwell, Fundamentals of Corporate Finance, Wiley, New York 2008.

PETERSON R., E.A. Silver, Decision Systems for Inventory Management and Production Planning, Wiley, New York 1979.

PIOTROWSKA M., Short-term financial decisions, WUE, Wroclaw 1997. PLOSSL G.W., Production and Inventory Control, Principles and

Techniques, Prentice Hall, Englewood Cliffs 1985.

POTESHMAN A., R. PARRINO, M. WEISBACH, Measuring Investment

Distortions when Risk-Averse Managers Decide Whether to Undertake Risky

Project, Financial Management, vol. 34, Spring 2005, p. 21-60.

REILLY F.K., Investments, The Dryden Press, Fort Worth 1992.

STONE B. K., The Use of Forecasts and Smoothing in Control - Limit

Models for Cash Management, Financial Management, 1972, p. 72-84.

TOBIN J., Liquidity Preference as Behavior Toward Risk, Review of Economic Studies, 1958 r. nr 25, p. 65-86. 